УДК 004:853

DOI: $10.37026 / 2520-6427-2021-107-3-86-90$
Валентина КОВАЛЕНКО,

кандидат педагогічних наук, стариий науковий співробітник відділу хмаро орієнтованих систем інформатизаиії освіти Інституту інформаційних технологій i засобів навчання НАПН Украӥни,

м. Київ, Украӥна

ORCID: 0000-0002-4681-5606

e-mail:vako88@ukr.net

\section{Майя МАР'ЄНКО,}

кандидат педагогічних наук,

стариий науковий співробітник відділу

хмаро орієнтованих систем інформатизаиії освіти

Інституту інформаційних технологій

$i$ засобів навчання НАПН України,

м. Київ, Украӥна

ORCID: 0000-0002-8087-962X

e-mail:popelmaya@gmail.com

\section{Аліса СУХІХ,}

кандидат педагогічних наук,

старший науковий співробітник відділу

хмаро орієнтованих систем інформатизаиії освіти

Інституту інформаційних технологій

$i$ засобів навчання НАПН України,

м. Київ, Украӥна

ORCID: 0000-0001-8186-1715

e-mail:alisam@ukr.net

\title{
ОСОБЛИВОСТІ ВПРОВАДЖЕННЯ ЗМІШАНОГО НАВЧАННЯ У ЗАКЛАДАХ ЗАГАЛЬНОЇ СЕРЕДНЬОЇ ОСВІТИ
}

\begin{abstract}
Анотація. У статті розглядаються особливості впровадження змішаного навчання у закладах загальної середньої освіти. Проаналізовано наукові дослідження та публікаиії з означеного питання, визначено, в яких роботах досліджено проблему впровадження змішаного навчання в заклади освіти. У представленому дослідженні змішане навчання розглядається як освітня кониепиія, суб'єктами якої $\epsilon$ учень та вчитель. Уточнено особливості змішаного навчання та розглянуто моделі дистанційного навчання. Проілюстровано відмінності між поняттями «змішана модель навчання» та «змішане навчання». Проаналізовано моделі зміманого навчання: face-tofасе, одночасна робота груп, ротаиії, перевернутий клас. Визначено умови, за яких відбувається вибір моделі використання дистаниіийних технологій навчання.
\end{abstract}

Окреслено переваги застосування у роботі вчителя хмарного сервісу Google Classroom. Окремим пунктом розглянуто інформаційну безпеку під час упровадження змішаного навчання, зокрема досліджено не лише безпеку в хмаро орієнтованих системах навчання, але й психологічну безпеку та психологічний комфорт під час використання означених систем. Проведено опитування шодо визначення причин, чому учні не вмикають камери чи мікрофони у ході проведення дистанційного уроку. Встановлено, щзо якість навчання у змішаному форматі передусім залежсть від готовності вчителя адаптувати свій підхід до викладу матеріалу у навчальному процесі.

Ключові слова: змішане навчання, модель змішаного навчання, заклади загальної середньої освіти, циифрові технології, вчителі, учні.

\author{
Valentyna KOVALENKO, \\ Candidate of Pedagogical sciences, \\ Senior Researcher of the Departmant \\ of Cloud-Oriented Systems \\ of Education Informatization, \\ Institute of Information Technologies and \\ Learning Tools of NAES of Ukraine, \\ Kyiv, Ukraine \\ ORCID: 0000-0002-4681-5606 \\ e-mail:vako88@ukr.net
}




\author{
Maya MARIENKO, \\ Candidate of Pedagogical sciences, \\ Senior Researcher of the Department \\ of Cloud-Oriented Systems \\ of Education Informatization, \\ Institute of Information Technologies and \\ Learning Tools of NAES of Ukraine, \\ Kyiv, Ukraine \\ ORCID: 0000-0002-8087-962X \\ e-mail: popelmaya@gmail.com \\ Alisa SUKHIKH, \\ Candidate of Pedagogical sciences, \\ Senior Researcher of the Departmant \\ of Cloud-Oriented Systems \\ of Education Informatization, \\ Institute of Information Technologies and \\ Learning Tools of NAES of Ukraine, \\ Kyiv, Ukraine \\ ORCID: 0000-0001-8186-1715 \\ e-mail:alisam@ukr.net
}

\title{
FEATURES OF IMPLEMENTATION OF BLENDED LEARNING IN GENERAL SECONDARY EDUCATION INSTITUTIONS
}

\begin{abstract}
The article considers the peculiarities of the introduction of blended learning in general secondary education. The latest research and publications are analyzed. It hast been determined in which works the problem of introduction of blended learning in educational institutions was investigated. In this study, blended learning is seen as an educational concept in which the subjects are the student and the teacher. Features of mixed learning are specified. Models of distance learning are considered. The differences between the concepts of «Blended learning model» and «Blended learning» are shown.

It has been analyzed such models of blended learnin: face-to-face, simultaneous work of groups, rotations, inverted class. The conditions under which the choice of the model of using distance learning technologies takes place are determined. The advantages of using the Google Classroom cloud service as a teacher are outlined. A separate item discusses information security during the implementation of blended learning.

In particular, not only safety in cloud-based learning systems, but also psychological safety and psychological comfort when using these systems were studied. A survey was conducted to determine the reasons why students do not turn on cameras or microphones during a distance lesson. It is established that the quality of teaching in a mixed format primarily depends on the willingness of the teacher to adapt their approach to the presentation of material in the learning process.

Key words: blended learning, blended learning model, general secondary education institutions, digital technologies, teachers, students.
\end{abstract}

Постановка проблеми. Потреба у нових підходах до навчання, враховуючи обмеження кількості занять у класі, залишається проблемним питанням для адміністрації закладів загальної середньої освіти, вчителів, учнів та їх батьків.

Запровадження змішаної моделі навчання - це можливість отримання знань як у класі, так і поза ним. Завдяки вдосконаленню шкільної програми і цифрових технологій змішане навчання продовжує набирати обертів.

Водночас украй актуальними лишаються такі вимоги до загальної середньої освіти, як: доступність для окремих категорій учнів; інклюзивність; урахування санітарних норм; взаємодія дітей з учителями та однокласниками та ін. Вирішення цих питань неможливе без широкомасштабного впровадження онлайн-технологій, грунтовних змін у підходах до організації навчання в закладах загальної середньої освіти.

Аналіз наукових досліджень і публікацій. Проблема впровадження змішаного навчання в заклади освіти на різних рівнях освіти розкрита у роботах таких авторів, як А. Андрєєв, І. Ахмад, Н. Балик В. Биков, К. Бугайчук, Ю. Капустін, Н. Корсунська, О. Кривонос, В. Кухаренко, М. Лещенко, Н. Рашевська, В. Солдаткін, А. Стрюк, О. Тихомирова, Ю. Триус, Г. Чередніченко, Л. Шапран, Т. Шроль, Б. Шуневич та ін.

Мета статті - визначити особливості впровадження змішаного навчання у закладах загальної середньої освіти.

Виклад основного матеріалу дослідження. Змішане навчання - це освітня концепція, в рамках якої учень отримує знання як дистанційно через мережу «Інтернет», так і очно з учителем. Такий підхід дає можливість контролювати час, місце та темп власного навчання. Крім того, означена модель дозволяє поєднувати традиційні методики та актуальні технології.

Під час змішаного навчання матеріали подаються в електронному вигляді, існує можливість здавати 
роботу в електронному вигляді, відбувається регулярне оцінювання з коментарями, надається можливість групової роботи, існують засоби електронного відслідковування успішності (електронні журнали); очне навчання базується на принципах інтерактивності (Кухаренко, 2015).

Особливостями змішаного навчання є: необмежений зміст, урахування освітніх потреб, індивідуальний освітній маршрут кожної дитини, зміна ролі педагога від вертикального домінування до горизонтальної взаємодії і модерації, збільшення впливу не зовнішньої оцінки, а самооцінки та взаємооцінювання (Моделі змішаного навчання: особливості, поради, успішні приклади, 2019). При виборі моделі дистанційного навчання кожен учитель повинен ретельно проаналізувати зміст уроків і зрозуміти, який матеріал учні можуть опанувати самостійно за допомогою цифрових технологій, та визначити, які навчальні заходи найбільш важливі для спільної роботи.

Змішана модель навчання - це модель використання розподілених інформаційно-освітніх ресурсів у стаціонарному навчанні із застосуванням елементів асинхронного й синхронного дистанційного навчання (Бугайчук, 2016)

Тобто змішане навчання - це термін, що поєднує різні практики навчання та навчальний досвід завдяки деякій комбінації як очної, так і опосередкованої технологій навчання. Під час опосередкованих технологій учням не потрібно фізично знаходитися разом в одному місці, вони можуть працювати через підключення до мережі «Інтернет».

До моделей змішаного навчання належать (Моделі змішаного навчання: особливості, поради, успішні приклади, 2019):

1. Face-to-face - значна частина матеріалу вивчається при очній взаємодії з вчителем. Електронне навчання може використовуватися як додатково, так i одночасно з очною формою.

2. Одночасна робота груп. Модель можна використовувати, якщо учнів класу об'єднати у дві групи. Для першої впроваджується очне, традиційне навчання у класі, а для другої у цей же час транслюється урок. Після цього групи міняються місцями. Означена модель застосовується за умови обладнання класу комп'ютерною технікою (комп'ютер або ноутбук підключений до швидкісного інтернету, наявна вебкамера, мікрофон, гучномовець). Учитель повинен мати цифрові навички проведення відеоконференцій, спілкування онлайн тощо. В умовах тільки очного навчання модель також може використовуватись, якщо учням після очної взаємодії надаються е-ресурси для самостійного поглибленого вивчення теми.

3. Ротаціï. Ротаційна модель з онлайн-станціями. Наприклад, частина класу проходить навчання дистанційно, а частина - працює з учителем. Потім вони міняються місцями. Школа може вибрати ротації і для окремих предметів. Наприклад, після аналізу освітньої програми та електронних освітніх ресурсів із певного предмета вчитель визначився, що впродовж тижня він може працювати з учнями онлайн (синхронно та асинхронно), а на наступному тижні - опрацьовувати тему в класі. Як виняток, у разі потреби весь клас залучається до очного навчання, але за цієї умови виконуються карантинні обмеження, можна задіяти актові зали, рекреації.

4. «Перевернутий клас». На сайті, блозі або дистанційній платформі заздалегідь розміщуються теми, дистанційні практичні роботи. Завдання виконуються вдома, а на заняттях обговорюються незрозумілі питання, поглиблено вивчається тема. Вчитель планує заняття таким чином, щоб частина роботи була онлайн (тестування, моделювання, робота у проєкті, розв'язання задач тощо). У цій моделі вчитель має спланувати роботу так, щоб учні двох підгруп мали можливість взяти участь і в роботі онлайн-станції, і на уроці. Для планування занять онлайн педагогу краще використовувати освітню програму протягом тижня, якщо предмет викладається більше двох уроків на тиждень, i декількох тижнів, якщо кількість уроків - один-два на тиждень.

Незважаючи на існування чотирьох базових моделей змішаного навчання, можливостей його використання нескінченно багато, коли мова заходить про способи, якими можна поєднати навчальні технології у педагогічному підході вчителя.

Вибір моделі використання дистанційних технологій навчання цілком залежить від зовнішніх умов (наприклад, карантинні обмеження) та особливостей i потреб кожного навчального закладу, а саме:

- кількості учнів;

- площі приміщень;

- цифрової компетентності учасників освітнього процесу;

- наявності електронного інформаційно-освітнього середовища, яке не тільки забезпечує поширення інформації (сайт школи), а й комунікацію і співпрацю учнів та вчителів онлайн, у тому числі з проведенням онлайн-уроків на відстані (наприклад, за допомогою дистанційної платформи);

- відповідно до особливостей закладу освіти (Моделі змішаного навчання: особливості, поради, успішні приклади, 2019).

М. Лещенко та Л. Тимчук вважають, що педагогічні працівники як представники «інформаційної спільноти» стоять перед альтернативою виконання нових особистих ролей або альтернативою вибору варіантів поведінки в мережі й контролю за власними діями в ній, що пов'язано з проблемою розвитку компетентності щодо використання IКТ. Важливими є такі вміння вчителя: участь у створенні спільноти у процесі мережної комунікації, зокрема побудова структур мережних взаємозв'язків і контактів; уміння реагувати на питання, проводити діалог, а також виробляти індивідуальний підхід, позбавляючись стереотипів і формалізованої поведінки; дотримання сфери приватності, тобто у процесі інтеркомунікації контролювати емоції, почуття і висловлення, щоб не перетнути межі приватного простору особистості; акцентування на створенні образної презентації, що призводить до виникнення відчутних особистих і соціальних реакцій (Лещенко, Тимчук, 2014).

Нині у період карантинних обмежень та актуалізації дистанційного навчання вчителі активніше почали використовувати хмарні сервіси, зокрема 
Google Classroom для організації освітнього процесу. Це безкоштовний сервіс, мета якого спрямована на спрощення організації освітнього процесу закладів освіти в дистанційному режимі. За допомогою Google Classroom учителі можуть створювати завдання для учнів та оцінювати їх виконання, надавати рекомендації, завантажувати методичні матеріали тощо.

До основних переваг використання у роботі вчителя хмарного сервісу Google Classroom належать (Коваленко, 2021):

- учитель може створювати не один клас, а декілька, які зберігаються на Google Диску педагога до того часу, поки вчитель сам не видалить клас;

- завдання автоматично відправляються на електронну пошту учня та зберігаються на Google Диску, також учні можуть додавати додаткові документи, таблиці, презентації тощо до виконаного завдання зі свого Google Диска чи ПК, ноутбука, планшета, телефона чи іншого пристрою; вчитель може встановити терміни виконання завдання та прослідкувати несвоєчасне його виконання;

- оцінювання завдань учнів учителем відбувається шляхом виставлення балів за кожне виконане завдання, отримані бали вчитель може редагувати за умов доопрацювання / виправлення завдання. Також учитель може призначати індивідуальні додаткові завдання кожному учню для покращення оцінки / підвищення балів;

- учителі, окрім електронної пошти Gmail, можуть опублікувати оголошення чи рекомендації у загальний потік Classroom, таким чином, інформуючи про заняття онлайн тощо;

- Classroom можна заархівувати в кінці семестру або навчального року і відновити за потребою;

- у Classroom учитель додає матеріал, який не може видалити ніхто, крім нього, також тільки вчитель може додавати і видаляти користувачів (учнів у Classroom);

- Google Classroom можна використовувати разом 3 іншими додатками від Google, приміром, електронною поштою Gmail, Google Meet, Google Документи, Google Таблиці, Google Презентації, Google Форми, Google Сайти, Google Calendar, Google Диск та ін.

Аналізуючи змішане навчання, слід не забувати про інформаційну безпеку. Системи для керування дистанційним навчанням або цифрові інструменти, які використовуються для цього, мають бути доступними i захищеними. Необхідно забезпечити дотримання вимог чинного законодавства щодо нерозголошення персональних даних учасників освітнього процесу. Для унеможливлення несанкціонованих входів користувачів, які не $\epsilon$ членами групи навчання під час онлайн-конференцій, необхідно надавати покликання-запрошення тільки в закриті групи спілкування. Для приєднання учасників відеоконференцій, тестування, різних типів опитування покликання необхідно відправляти на електронну пошту респондентів для ідентифікації учасників. За можливості при проведенні тестування запитувати електронні адреси. Учителі повинні користуватися такими цифровими інструментами, що надають їм можливість модерувати освітній процес (керування мікрофонами учасників відеозустрічей, трансляціями екранів, вилучення учасників із конференції). В освітньому процесі використовувати лише перевірені та апробовані електронні освітні ресурси.

У контексті безпеки в хмаро орієнтованих системах навчання важливою $є$ тема психологічної безпеки та психологічного комфорту під час використання цих систем. Такі хмарні сервіси, як Google Classroom та Microsoft Teams, наразі стали ще популярнішими, ніж два-три роки тому. Під час проведення занять, за допомогою Google Classroom та Microsoft Teams, учителі часто не можуть збагнути, чому певна частина учнів не вмикають камери та звук під час занять.

Виявилося, що коли учень не вмикає камеру, він відчуває себе у безпеці, почувається комфортніше, аніж з увімкненою камерою та звуком. Основними причинами цього, згідно 3 проведеним опитуванням 16 респондентів, $\epsilon$ :

- страх публічних виступів, особливо перед камерою («боюсь сказати щось не те», «а раптом хтось записує зустріч і буде потім насміхатися»);

- члени сім'ї, які знаходяться поруч, втручаючись у хід заняття чи спілкуючись за кадром, викликають осуд із боку ровесників;

- у 15\% опитаних не має робочого місця, що не дозволяє сконцентруватися на навчальному матеріалі та породжує страх потрапляння в кадр членів сім'ї та домашніх тварин;

- несприятливі умови проживання (відсутність сучасного ремонту в квартирі, старі меблі тощо), страх осуду однолітків;

- 22\% учнів відмітили некомфортні умови для відвідування занять.

Педагогічна майстерність та постійне підвищення цифрової компетентності вчителів допоможе створити сприятливі умови задля комфортного та безпечного самопочуття учнів.

Якість навчання у змішаному форматі передусім залежить від готовності вчителя адаптувати свій підхід до викладу матеріалу, методів навчання та розуміння ролі вчителя й учнів у навчальному процесі. Цифрова компетентність учителя описана групою авторів під керівництвом Н. Морзе (Морзе, 2019) та передбачає наступні складники: інтеграція технологій, використання даних, персоналізація та безпека. На допомогу вчителю пропонуються курси підвищення кваліфікації. Складник «Інтеграція технологій» характеризується: вмінням використовувати цифрові технології, опановувати нові та ефективно комбінувати цифрові технології 3 очною формою навчання. «Використання даних» можна описати як контроль активності учнів, управління прогресом навчання, дистанційне оцінювання навчальних досягнень, а складник «Персоналізація та безпека» - як проєктування освітнього середовища, розробка ресурсів, зворотний зв'язок та взаємодія між учителем та учнями, групова співпраця.

Висновки. Таким чином, використання змішаного навчання спроможне якісно змінити процес підготовки учнів у З3СО, сприяє активному впровадженню та оновленню цифрових технологій. Однак усе це стає можливим лише за умови, якщо вчитель створює єдиний дидактичний комплекс $з$ інформаційно-освітнім середовищем, що не дублює базовий підручник, 
а збагачує й поглиблює навчальний матеріал за рахунок можливостей, котрі надають сучасні цифрові технології.

Перспективи подальших досліджень спрямовані на обгрунтування і розроблення методики використання цифрових технологій у процесі змішаного навчання в закладах загальної середньої освіти.

Статтю виконано в рамках наукового дослідження «Використання цифрових технологій у процесі змішаного навчання в закладах загальної середньої освіти» (ДР № 0121U108755).

\section{СПИСОК ВИКОРИСТАНОӤ ЛІТЕРАТУРИ}

Кухаренко, В. М. (2015). Системний підхід до змішаного навчання. Інформаційні технології в освіті. № 24. С. 53-67.

Моделі змішаного навчання: особливості, поради, успішні приклади. EdEra R\&D: вебсайт. URL: https:// qrgo.page.link/nCfvp (дата звернення: 17.06.2021).

Бугайчук, К. Л. (2016). Змішане навчання: теоретичний аналіз та стратегія впровадження в освітній процес вищих навчальних закладів. Інформаційні технології $і$ засоби навчання. № 4. C. 1-14. URL : https:// journal.iitta.gov.ua/index.php/itlt/article/view/1434/1070 (дата звернення: 18.06.2021).

Лещенко, М. П., Тимчук, Л. І. (2014). Розвиток медіакомпетентностей учителів у сучасному інформаційному суспільстві: польський досвід. Формування інформаційно-комунікаційних компетентностей у контексті євроінтеграційних процесів створення інформачійного освітнього простору: посібник / за заг. ред. В. Ю. Бикова, О. В. Овчарук; НАПН України; Ін-т інформ. технол. і засобів навч. Київ: Атіка. С. 122-138.

Коваленко, В. В. (2021). Використання хмарних сервісів для підвищення кваліфікації вчителів. Теоретико-практичні проблеми використання математичних методів і комп'ютерно-орієнтованих технологій в освіті та науціi: матеріали III Всеукраїнської науково-практичної онлайн-конференції. URL : https:/drive. google.com/file/d/1kZokuhuCnVNw2zOTDKOypcFtm2C $16 \mathrm{pEq} /$ view (дата звернення: 02.06.2021).

Морзе, Н. та ін. (2019). Опис цифрової компетентності педагогічного працівника. Відкрите освітне е-середовище сучасного університету: спецвипуск. C. 1-53. URL: https://doi.org/10.28925/24140325.2019s39 (дата звернення: 17.06.2021).

\section{REFERENCES}

Kukharenko, V. M. (2015). Systemnyi pidkhid do zmishanoho navchannia [Systematic approach to blended learning]. Informatsiini tekhnolohii v osviti. № 24. S. 53-67. [in Ukrainian].

Modeli zmishanoho navchannia: osoblyvosti, porady, uspishni pryklady [Models of blended learning: features, tips, successful examples]. EdEra $R \& D$ : vebsait. URL: https://qrgo.page.link/nCfvp (data zvernennia: 17.06.2021). [in Ukrainian].

Buhaichuk, K. L. (2016). Zmishane navchannia: teoretychnyi analiz ta stratehiia vprovadzhennia v osvitnii protses vyshchykh navchalnykh zakladiv [Blended learning: theoretical analysis and strategy of introduction of higher educational institutions into the educational process]. Informatsiini tekhnolohii i zasoby navchannia. № 4. S.1-14. URL: https://journal.iitta.gov.ua/index.php/itlt/ article/view/1434/1070 (data zvernennia: 18.06.2021). [in Ukrainian].

Leshchenko, M. P., Tymchuk, L. I. (2014). Rozvytok mediakompetentnostei uchyteliv u suchasnomu informatsiinomu suspilstvi: polskyi dosvid [Development of teachers' media competencies in the modern information society: the Polish experience]. Formuvannia informatsiino-komunikatsiinykh kompetentnostei u konteksti yevrointehratsiinykh protsesiv stvorennia informatsiinoho osvitnoho prostoru: posibnyk / za zah. red. V. Yu. Bykova, O. V. Ovcharuk; NAPN Ukrainy; In-t inform. tekhnol. i zasobiv navch. Kyiv: Atika. S. 122-138. [in Ukrainian].

Kovalenko, V. V. (2021). Vykorystannia khmarnykh servisiv dlia pidvyshchennia kvalifikatsii vchyteliv [Using of cloud services to improve teachers skills]. Teoretyko-praktychni problemy vykorystannia matematychnykh metodiv i kompiuterno-oriientovanykh tekhnolohii v osviti ta nautsi: materialu III Vseukrainskoi naukovo-praktychnoi onlain-konferentsii. URL: https://drive.google. com/file/d/1kZokuhuCnVNw2zOTDKOypcFtm2Cl6pEq/ view (data zvernennia: 02.06.2021). [in Ukrainian].

Morze, N. ta in. (2019). Opys tsyfrovoi kompetentnosti pedahohichnoho pratsivnyka [Description of digital competence of a pedagogical worker]. Vidkryte osvitnie e-seredovyshche suchasnoho universytetu: spetsvypusk. S. 1-53. URL: https://doi.org/10.28925/2414-0325.2019s39 (data zvernennia: 17.06.2021). [in Ukrainian].

Дата надходження до редакиії: 15.06.2021 p. 